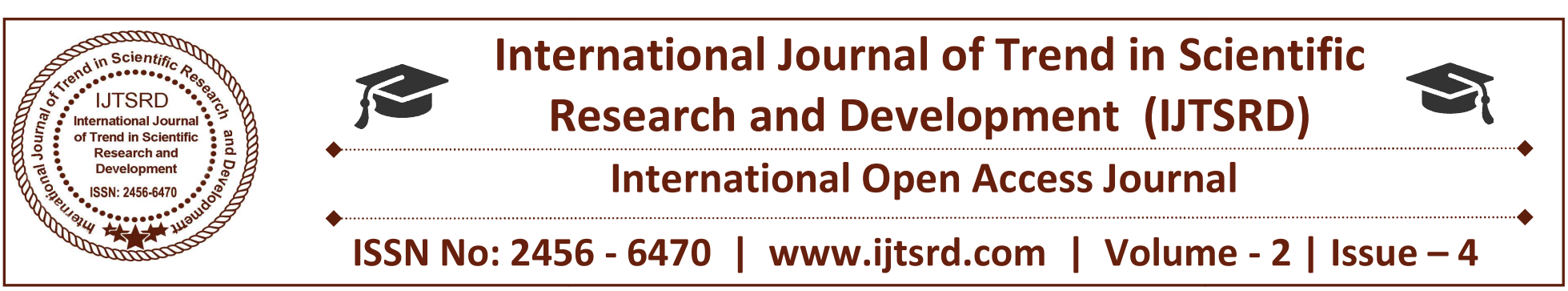

\title{
Performance and Emission Characteristics of Pyrolysed Fuel of Tyre Blended with Diesel in Diesel Engine
}

\author{
K. Saravanan, Pon. Azhagiri, Dr. T. Senthil Kumar \\ Department of Mechanical Engineering \\ University College of Engineering, BIT Campus, Tiruchirappalii, Tamil Nadu, India
}

\begin{abstract}
The waste management of scrap tyre causes impact on environment due to its non-degradable property. Therefore the recycling of tyre scrap is to be considered for improving the energy conversion from solid waste management. The objective of this project is to investigate the performance and emission characteristics of diesel blended with Tyre Prolysis Oil(TPO) in direct injection(DI) diesel engine. The tyre oil obtained at $713 \mathrm{~K}$ through pyrolysis process of waste tyre. The synthesized oil is then processed by desulphurization to reduce the sulphur content and transesterification for blending it with diesel. The various blends of composition 10\% TPO and 90\% diesel, 20\% TPO and $80 \%$ diesel is prepared. Through these blends the improvement of performance and emission characteristics such as $\mathrm{NOX}, \mathrm{CO} 2, \mathrm{HC}$ were identified and compared with conventional diesel fuel.
\end{abstract}

Keywords: Fin; Waste management; Tyre Pyrolysis Oil; Desulphurization; Emission Characteristics.

\section{INTRODUCTION}

Day-to-day, the fuel economy of engines is getting improved and will continue to improve. However, the enormous increase in number of vehicles has been meeting the current demand for fuel. Gasoline and Diesel will become scarce and more costly in the future. With the increased use and depletion of fossil fuels, alternative fuel technology will become in the coming decades. By motivating the development of alternate fuels for the IC engine is the concern over the emission problems of gasoline and diesel engines. Combined with other air polluting systems, the large number of automobiles is a major contributor to the air quality problem of the world. Another reason for

the development of alternate fuel technology is the fact that a large percentage of crude oil must be imported from various countries which control the larger oil fields.

\section{Natural Air Cooling}

\subsection{PRIMARY ENERGY SOURCES}

Primary energy sources can be defined as sources which provide a net supply of energy. Coal, oil, uranium etc. The energy required to obtain these fuels is much less than what they can produce by combustion or nuclear reaction. Their energy yield ratio, which is the energy fed back by the material to the energy received from the environment is very high.

The primary fuels only can accelerate growth but their supply is limited. It becomes very essential to use these fuels sparingly. Primary fuels contribute considerably to the energy supply.

\subsection{SECONDARY FUELS}

They produce no net energy. Though it may be necessary for the economy, these may not yield net energy. Intensive agriculture is an example wherein terms of energy the yield is less than input.

\subsection{SUPPLEMENTARY SOURCES}

These are defined as those whose net energy yield is zero and those requiring highest investment in terms of energy. Insulation (thermal) is an example for this source. Coal, natural gas, oil and nuclear energy using breed or reactor are net energy yielders and are 
International Journal of Trend in Scientific Research and Development (IJTSRD) ISSN: 2456-6470

primary sources of energy. Secondary sources are like solar energy, wind energy, water energy etc.

\section{PROBLEM IDENTIFICATION}

Nowadays, the cost of fuel is increased due to increase in demand of fuel and hence it is important to reduce the cost.

The emissions of $\mathrm{NOx}, \mathrm{HC}, \mathrm{CO}, \mathrm{CO}_{2}$, etc causes environmental pollution.

$>$ The viscosity of the fuel used is high.

$>$ There is an incomplete combustion of fuel in the engine.

\section{EXTRACTION OF OIL FROM PYROLYSIS} SET UP

$>$ The waste tyre is cut into small pieces. It is then washed with water to remove dust and impurities. The wet tyre is then dried to remove water content.

$>$ After 20 minutes vapour is starts produced at the temperture of $370^{\circ} \mathrm{C}$. The water supply is provided to condenser in the cross flow direction. The water starts to condense the hot vapour into liquid(TPO) at $440^{\circ} \mathrm{C}$.

$>$ The oil is collected in the separate chamber and total yield from $2 \mathrm{~kg}$ of waste tyre is about $820 \mathrm{ml}$. The pyrolysis set up is shown in figure 4.1below.

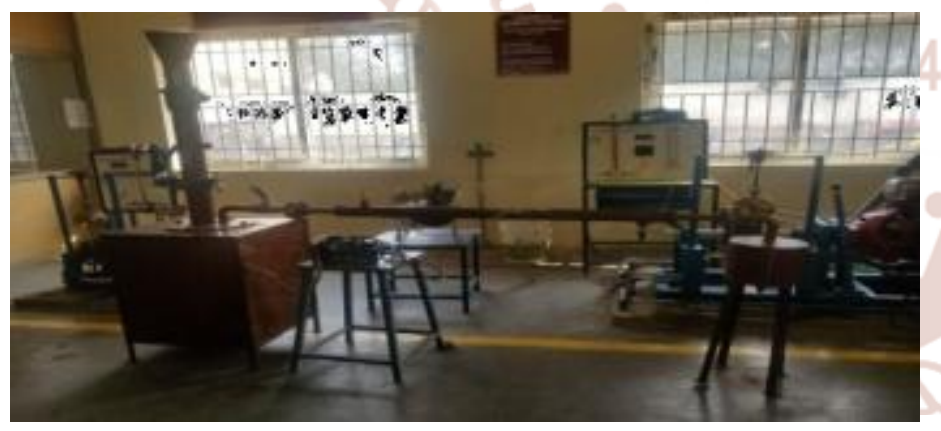

Figure 4.1 Pyrolysis Set-Up

\subsection{DESULPHURIZATION}

Desulphurization is a chemical process to remove the sulphur from a liquid. TPO of 750 $\mathrm{ml}$ is heated at $60^{\circ} \mathrm{C}$ for 20 minutes in an electric heater.

$>$ Sulphuric acid (H2SO4) of $150 \mathrm{ml}$ is added to the heated TPO and stirred continuously. After 3 hours it is then allowed to cool.

$>$ After 48 hours the sulphur and impurities are precipitated in the bottom layer. The top layer is the required TPO and the yield is about 620 $\mathrm{ml}$.

\subsection{TRANSESTERIFICATION}

$>$ The process of exchanging the organic group of an ester with an organic group of alcohol often catalyzed by the addition of acid or base catalyst.

A mixture of $\mathrm{KOH}(1.4 \mathrm{~g})$ and methanol $(240 \mathrm{ml})$ is prepared.

The TPO $(520 \mathrm{ml})$ is heated around $333 \mathrm{~K}$ for 20 minutes in magnetic stirrer.

After 20 minutes, $104 \mathrm{ml}$ of methanol and $\mathrm{KOH}$ mixture is added to TPO.

Maintain temperature at $333 \mathrm{~K}$ for one hour and allow it to cool.

The processed oil is kept for 48 hours in room temperature without any disturbances.

$>$ The biodiesel (ester) obtained at top layer and the glycerol obtained at bottom layer.

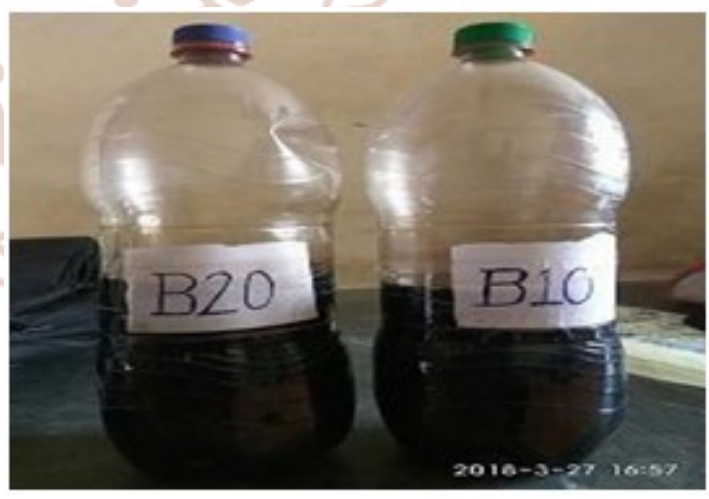

Figure 3.6 Fuel Blends - B10 and B20 


\section{PROPERTIES OF TPO AND FUEL BLEND}

\begin{tabular}{|c|c|c|c|c|c|}
\hline FUEL & $\begin{array}{l}\text { DENSITY } \\
\left(\mathrm{Kg} / \mathrm{m}^{\wedge} 3\right)\end{array}$ & $\begin{array}{l}\text { DYNAMIC } \\
\text { VISCOSITY } \\
\left(\mathrm{Ns} / \mathbf{m}^{2}\right)\end{array}$ & $\begin{array}{l}\text { KINEMATIC } \\
\text { VISCOSITY } \\
\left(\mathrm{m}^{2} / \mathrm{sec}\right)\end{array}$ & $\begin{array}{l}\text { FLASH } \\
\text { POINT } \\
\text { PC }\end{array}$ & $\begin{array}{l}\text { FIRE } \\
\text { POINT } \\
\text { PC }\end{array}$ \\
\hline TPO & 838.6 & 0.0185 & $2.21 \times 10^{-5}$ & 65 & 68 \\
\hline B10 & 837.08 & 0.0192 & $2.34 \times 10^{-5}$ & 56 & 59 \\
\hline B20 & 835.54 & 0.0204 & $2.48 \times 10^{-5}$ & 54 & 56 \\
\hline
\end{tabular}

\section{PERFORMANCE CHARACTERISTICS}

Fuel : Diesel

\begin{tabular}{|c|c|c|c|c|c|c|c|c|}
\hline $\begin{array}{c}\text { POWER } \\
(\mathbf{k W})\end{array}$ & $\begin{array}{c}\text { TFC } \\
(\mathrm{kg} / \mathrm{hr})\end{array}$ & $\begin{array}{l}\mathrm{BP} \\
(\mathrm{kW})\end{array}$ & $\begin{array}{c}F P \\
(\mathrm{~kW})\end{array}$ & $\begin{array}{c}\text { IP } \\
\mathbf{k W})\end{array}$ & $\begin{array}{c}\text { SFC } \\
(\mathrm{kg} / \mathbf{k W}-\end{array}$ & $\begin{array}{c}\text { nmech } \\
\%\end{array}$ & noverall & $\begin{array}{c}\text { nthermal } \\
\%\end{array}$ \\
\hline 0.5 & 0.516 & 1 & $2.65 \mathrm{er}$ & 3.650 & $0.516 \mathrm{OU}$ & 27.39 & 15.86 & 57.89 \\
\hline 1 & 0.562 & 1.35 & $2.65-$ & & 0.416 & 33.75 & 19.66 & 58.27 \\
\hline 1.5 & 0.673 & 2.18 & 2.65 & 4.83 & 0.308 & 45.13 & 26.5 & 58.75 \\
\hline
\end{tabular}

Fuel: Diesel (90\%) and TPO(10\%)

\begin{tabular}{|c|c|c|c|c|c|c|c|c|}
\hline $\begin{array}{c}\text { POWER } \\
(\mathrm{kW})\end{array}$ & $\begin{array}{c}\text { TFC } \\
\text { (kg/hr) }\end{array}$ & $\begin{array}{c}\text { BP } \\
(\mathrm{kW})\end{array}$ & $\begin{array}{c}\text { FP } \\
(\mathbf{k W})\end{array}$ & $\begin{array}{c}\text { IP } \\
\text { SN: } \\
(\mathbf{k W})\end{array}$ & $\begin{array}{c}\mathbf{S F C} \\
56=64 \\
\mathbf{( k g / k W -} \\
\mathbf{h r})\end{array}$ & nmech & noverall & $\begin{array}{c}\text { nthermal } \\
\%\end{array}$ \\
\hline 0.5 & 0.502 & $14 \mathrm{~N}$ & 1.25 & 2.25 & 0.502 & 44.44 & 19.03 & 42.83 \\
\hline 1 & 0.547 & 1.5 & 1.25 & 2.75 & 0.3652 & 54.54 & 26.09 & 47.83 \\
\hline 1.5 & 0.641 & 1.667 & 1.25 & 2.917 & 0.384 & 57.14 & 24.77 & 43.4 \\
\hline
\end{tabular}

Fuel : Diesel (80\%) and TPO (20\%)

\begin{tabular}{|c|c|c|c|c|c|c|c|c|}
\hline $\begin{array}{c}\text { POWER } \\
(\mathbf{k W})\end{array}$ & $\begin{array}{c}\text { TFC } \\
\text { (kg/hr) }\end{array}$ & $\begin{array}{c}\text { BP } \\
(\mathbf{k W})\end{array}$ & $\begin{array}{c}\text { FP } \\
(\mathrm{kW})\end{array}$ & $\begin{array}{c}\text { IP } \\
(\mathrm{kW})\end{array}$ & $\begin{array}{c}\text { SFC } \\
\text { (kg/kW- } \\
\text { hr })\end{array}$ & $\begin{array}{c}\text { nmech } \\
\%\end{array}$ & $\begin{array}{c}\text { noverall } \\
\%\end{array}$ & $\begin{array}{c}\text { nthermal } \\
\%\end{array}$ \\
\hline 0.5 & 0.501 & 1 & 1.5 & 2.5 & 0.501 & 40 & 15.49 & 38.72 \\
\hline 1 & 0.567 & 3 & 1.5 & 3 & 0.189 & 50 & 20.53 & 41.07 \\
\hline 1.5 & 0.639 & 3.6 & 1.5 & 5.1 & 0.1775 & 70.58 & 43.7 & 61.95 \\
\hline
\end{tabular}




\section{EMISSION CHARACTERISTICS}

\subsection{EMISSION COMPARISON OF CARBON DIOXIDE}

\begin{tabular}{|c|c|c|c|c|}
\hline \multirow[b]{2}{*}{ S.NO } & \multirow{2}{*}{$\begin{array}{c}\text { POWER } \\
(W)\end{array}$} & \multicolumn{3}{|c|}{ CO2 (\% vol) } \\
\hline & & DIESEL & B10 & B20 \\
\hline 1 & 0 & 1.2 & 1.1 & 1.1 \\
\hline 2 & 500 & 1.2 & 1.2 & 1.3 \\
\hline 3 & 1000 & 1.5 & 1.4 & 1.5 \\
\hline 4 & 1500 & 1.9 & 1.9 & 2.1 \\
\hline
\end{tabular}

\subsection{Emission Comparison of Hydrocarbon}

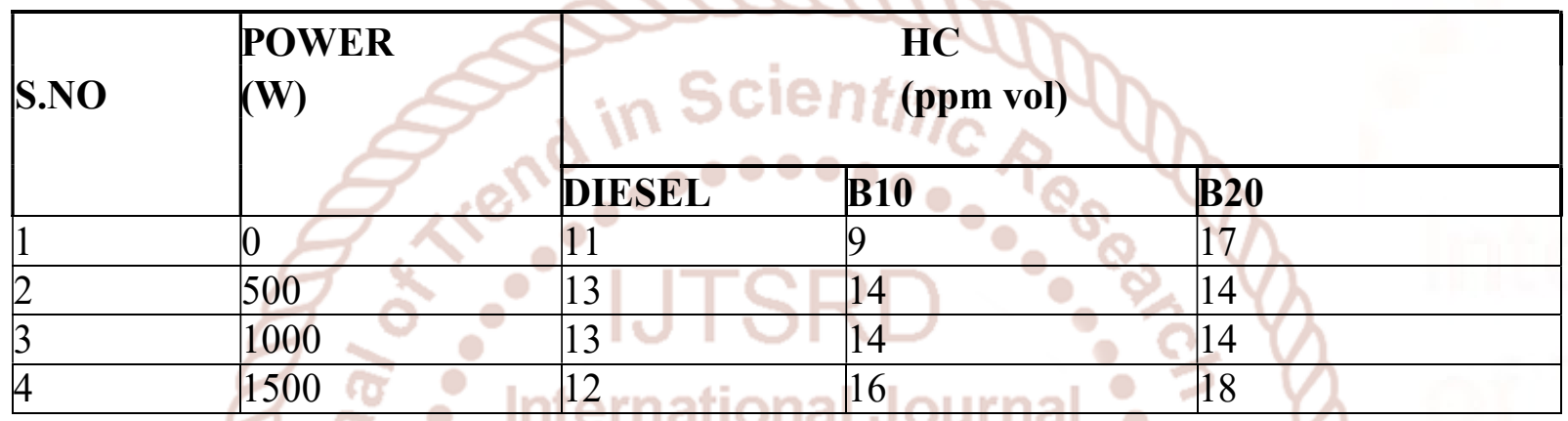

\subsection{Emission Comparison of Nitrogen Oxide}

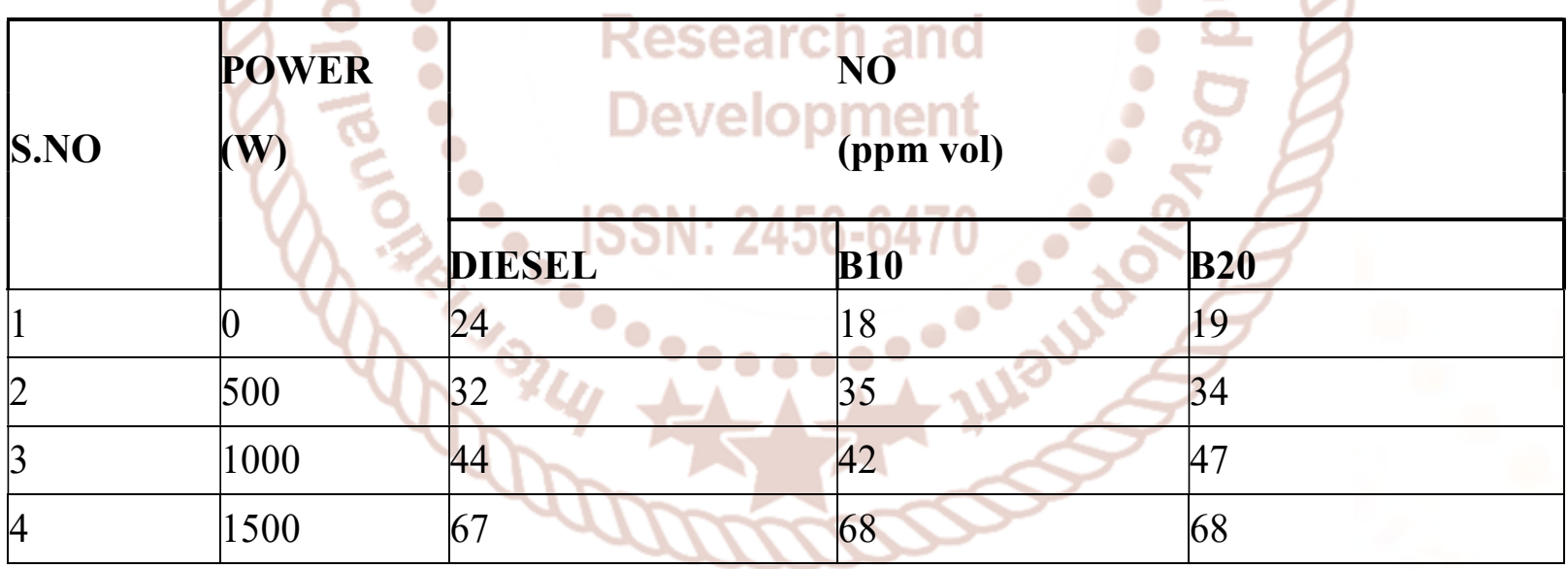

\section{CONCLUSION}

The objective of this project is to improve the performance and emission characteristics and the better results were observed in fuel blend B20 than B10 through this experiment.

In comparison of performance characteristics between diesel and fuel blend B20, the fuel blend B20 has maximum çmechanical of (70.48\%), $\square$ çoverall(43.7\%),çthermal(61.95\%) is greater than diesel performance and also the total fuel consumption B20 is lesser than the diesel.
$>$ The increase in performance of B20 over diesel is about çmechanical(56.17\%), çoverall(64.9\%), çthermal(5.44\%), $\mathrm{BP}(65.13 \%), \quad \mathrm{TFC}(5.05 \%)$, SFC( $42.37 \%)$.

$>$ In comparison with emission characteristics between diesel and B20, the emission is increased in very low content for B20 than diesel. The various emissions in $\mathrm{B} 20$ are $\mathrm{CO}-0.2(\% \mathrm{vol})$, $\mathrm{CO} 2$ - 2.1 (\% vol), HC - 18 (ppm vol), NO - 68 (ppm vol). The increase in emission of B20 over diesel is about $\mathrm{CO}(0 \%), \mathrm{CO} 2(9.52 \%), \mathrm{HC}$ 
International Journal of Trend in Scientific Research and Development (IJTSRD) ISSN: 2456-6470

$(50 \%)$, NO $(1.49 \%)$.

Though the fuel blend B20 has finite increase in $\mathrm{HC}$ emission and other negligible emission because of its better performance than diesel, thus the TPO blended in diesel of composition B20 can be also used in diesel engines as an alternative by reducing the $\mathrm{HC}$ emissions using some additives.

For better performance and good emission control fuel blended with the diesel (B20) TPO is suggested.

\section{REFERENCES}

1) Raj Mohamed[March 2016] Influence of substrate temperature on physical properties of (111)oriented CdIn2S4thin films by nebulized spray pyrolysis technique Journal of Asian Ceramic Societies Journal of Asian Ceramic Societies 4 (2016) 191-200.

2) Renato O. Arazo [July 2016] Bio-oil production from dry sewage sludge by fast pyrolysis in an electrically-heated fluidized bed II'reactor Sustainable Environment Research Sustainable Environment Research 27 (2016) 7e14.

3) J.L.H.P. Sallevelt [July 2016] Numerical study of pyrolysis oil combustion in an industrial gas turbine Energy Conversion and Management Energy Conversion and Management 127 (2016) 504-514.

4) Shilpa Agarwal [September 2016] Catalytic pyrolysis of recalcitrant, insoluble humin byproducts fromC6 sugar bio-refineries Journal of Analytical and Applied Pyrolysis Journal of Analytical and Applied Pyrolysis 123 (2017) 134143.

5) S.R.G. Oudenhoven [October 2016] Using pyrolytic acid leaching as a pretreatment step in a biomass fast pyrolysis plant: Process design and economic evaluation Biomass and Bio energy Biomass and Bioenergy 95 (2016) 388e404.

6) Siddharth Gadkari [October 2016] Numerical investigation of microwave-assisted pyrolysis of lignin Fuel Processing Technology Fuel Processing Technology 156 (2017) 473-484.

7) Arunkumar. G| Dr. P. Navaneetha Krishnan $\mid$ Dr. T. Senthil Kumar "Experimental Enhancement of
Heat Transfer Analysis on Heat Pipe using $\mathrm{SiO} 2$ and TiO2 Nano Fluid" Published in International Journal of Trend in Scientific Research and Development (ijtsrd), ISSN: 2456-6470, Volume2 Issue-4 , June 2018,URL: http://www.ijtsrd.com/papers/ijtsrd130 94.pdf

8) Jose L. Carrasco[January 2017] Pyrolysis of forest residues: An approach to techno-economics for bio-fuel production Fuel. Fuel 193 (2017) 477484.

9) IoannisKalargaris[March 2017] Experimental evaluation of a diesel engine fuelled by pyrolysis oils produced from low-density polyethylene and ethylene-vinyl acetateplastics Fuel Processing Technology Fuel Processing Technology 161 (2017) 125-131.

10)Uzun B [May 2017] Thermogravimetric characteristics and kinetics of scrap tyre and juglans negia shell co-pyrolysis. Waste management (2017) 32:961-70.

11) Williams PT [June 2017] Aromatic chemicals from the catalytic pyrolysis of scrap tyre. Pyrolysis (2017) 67:143-64

12) Cunliffe AM [July 2017] Composition of oils derived from the batch pyrolysis of scrap tyre. Pyrolysis (2017) 44:131-52.

13) Dogan O [August 2017] The effect of derived fuel blends utilization on diesel engine performance and emissions. Fuel (2017) 95:340-6. 